\title{
The formation of a new gustatory memory trace in rats is prevented by the noncompetitive NMDA antagonist ketamine
}

\author{
H. WELZL, B. ALESSANDRI, and K. BÄTTIG \\ Laboratory of Behavioral Biology, Swiss Federal Institute of Technology, Zurich, Switzerland
}

\begin{abstract}
Blockade of the NMDA receptor with competitive or noncompetitive antagonists prevents the induction of long-term potentiation and blocks some forms of learning. These results and theoretical considerations provide support for a role of the NMDA receptor in memory formation. We investigated the role of the noncompetitive NMDA antagonist ketamine in taste-aversion learning in rats. One hour after exposing the animals for the first time to a saccharin solution $(0.1 \%$; $\mathrm{CS}), \mathrm{LiCl}$ was injected to induce malaise (UCS). Forty-eight hours later, taste aversion was measured in a two-bottle choice test (saccharin vs. tap water). Ketamine $(25 \mathrm{mg} / \mathrm{kg}$ ) given $30 \mathrm{~min}$ before the first exposure to saccharin blocked taste-aversion learning. In contrast, animals injected with lower dosages ( 6 and $12 \mathrm{mg} / \mathrm{kg}$ ), as well as saline-injected control animals, developed a strong avoidance of the sweet solution. Ketamine $(25 \mathrm{mg} / \mathrm{kg})$ given $10 \mathrm{~min}$ before the $\mathrm{LiCl}$ injection (drug administration between the CS and the UCS) did not block the association between the newly acquired gustatory trace and the malaise. The results from control groups showed that ketamine did not interfere with the retrieval of an already acquired taste aversion and that the results were not due to state-dependency effects. The NMDA receptor appears to play a role in the acquisition of a new taste cue but not in the association of a new taste cue with malaise.
\end{abstract}

The NMDA receptor has been implicated in memory formation on the basis of several lines of evidence. First, this receptor fulfills a criterion for a "memory synapse" put forward by Hebb; that is, it is activated only if the pre- and postsynaptic membranes are depolarized (Smith, 1987). Second, NMDA receptor blockers impair longterm potentiation, which has been proposed as an electrophysiological model of memory (Collingridge, Kehl, \& McLennan, 1983; Morris, Anderson, Lynch, \& Baudry, 1986; Stringer \& Guyenet, 1983). Third, NMDA receptor blockers interfere with memory formation in several, but not all, learning tasks (e.g., see Alessandri, Bättig, \& Welzl, 1989; Morris et al., 1986). The effect of blockade of the NMDA receptor on the acquisition of a new gustatory memory trace in a conditioned tasteaversion paradigm has not yet been investigated.

Taste aversion is established in rats after only one pairing of a novel taste (e.g., saccharin) with malaise (e.g., gastrointestinal distress induced by an intraperitoneal injection of lithium chloride, $\mathrm{LiCl}$ ). Rats will then specifically avoid the taste associated with malaise. This learned aversion is known as conditioned taste aversion. Although the acquisition of the novel taste cue is subject to interference by a number of treatments (see Burěsová \& Burěs, 1973; Rondeau, Jolicoeur, Merkel, \& Wayner, 1981), the

This work was supported by a grant (3.184-0.88) from the Swiss National Foundation. We thank J. Nagel for her helpful comments on the manuscript. Correspondence may be addressed to H. Welzl, ETH Zürich, Laboratory of Behavioral Biology, Turnerstrasse 1, CH-8092, Zürich, Switzerland. association of the novel taste with malaise is difficult to block. The associative process can take place even under pentobarbital anesthesia (e.g., Burěsová \& Burěs, 1977). To collect further evidence for a role of the NMDA receptor in memory formation, we injected rats with the noncompetitive NMDA antagonist ketamine while the animals were submitted to taste-aversion learning. Our results suggest a role for the NMDA receptor in the formation of a new gustatory trace.

\section{METHOD}

\section{Subjects}

Seventy-two male Wistar rats $(280 \pm 20 \mathrm{~g})$ were housed in groups of 5 per cage with free access to food throughout the experiment. They were kept in an animal room maintained at about $20^{\circ} \mathrm{C}$ and on a 12:12 h light:dark cycle with lights on from 0600 to $1800 \mathrm{~h}$.

\section{Drug}

Ketamine (Ketalar, Parke-Davis \& Co.) was intraperitoneally injected either $10 \mathrm{~min}(6$ or $12 \mathrm{mg} / \mathrm{kg}$ ) or $30 \mathrm{~min}(25 \mathrm{mg} / \mathrm{kg})$ before the conditioned stimulus (CS), or $30 \mathrm{~min}(25 \mathrm{mg} / \mathrm{kg})$ before the unconditioned stimulus (UCS). The longer drug-trial delay for the $25-\mathrm{mg} / \mathrm{kg}$ groups allowed the rats to recover from the initial druginduced motor disturbances. Animals in the control group $(0 \mathrm{mg} / \mathrm{kg})$ were injected with saline before the presentations of the CS.

\section{Procedure}

The animals were first adapted to a restricted access to tap water ( $30 \mathrm{~min} / \mathrm{day}$ for 3 days) in their home cages. The daily drinking sessions during the experiment (Days 1-8) lasted $15 \mathrm{~min}$. All solutions were presented at room temperature (approximately $21^{\circ} \mathrm{C}$ ). During the first 5 days of the experiment, individual water consumption during the drinking sessions was measured in a test cage 
$(21 \times 37 \times 17 \mathrm{~cm})$. The test cages contained a full and an empty bottle with randomly interchanged positions.

On Day 6 (the conditioning day), the animals were divided into nine different drug-treatment groups $(N=8$ /group). The animals of Group 1, the control group, were injected with saline and, $10 \mathrm{~min}$ later, were allowed to drink a saccharin solution $(0.1 \%)$ presented in both bottles as the novel CS. One hour after the end of the drinking session in the test cage, they were injected with $\mathrm{LiCl}(0.14 \mathrm{M}, 2 \%$ body weight) as the UCS. On Day 7, tap water was again presented in one bottle with the other being empty. On Day 8 , the animals had a choice between a bottle containing the saccharin solution and another bottle containing tap water (two-bottle choice test) during their drinking session. The avoidance of the saccharin solution and preference for tap water in the two-bottle choice test (Dragoin, McCleary, \& McCleary, 1971; Grote \& Brown, 1971) on Day 8 was taken as a measure of successful taste-aversion learning.

Groups 2, 3, and 4-To establish a dose-response curve of the effect of ketamine on the acquisition of the CS, Groups 2, 3, and 4 were injected with 6,12 , and $25 \mathrm{mg} / \mathrm{kg}$ ketamine, respectively, instead of saline prior to the saccharin presentation.

Group 5-Because ketamine might also block the association between an already acquired gustatory trace and malaise, Group 5 was treated as Group 1, but was additionally injected with ketamine $(25 \mathrm{mg} / \mathrm{kg}$ ) $10 \mathrm{~min}$ prior to the $\mathrm{LiCl}$ injection (drug administration between the CS and the UCS).

Group 6-To determine the effects of ketamine on retrieval, Group 6 was injected with ketamine $(25 \mathrm{mg} / \mathrm{kg}$ ) prior to the twobottle choice test (saccharin vs. water) on Day 8 .

Group 7-Because a lack of taste-aversion learning in animals injected with ketamine before the CS presentation on Day 6 could be attributed to state-dependency, Group 7 was injected with ketamine $(25 \mathrm{mg} / \mathrm{kg}$ ) not only prior to the CS presentation on Day 6 (the conditioning day), as was Group 4 , but also prior to the CS presentation on Day 8 (two-bottle choice test).

Group 8-In contrast to the control group, the rats in Group 8 received a ketamine injection $(25 \mathrm{mg} / \mathrm{kg}$ ) instead of an $\mathrm{LiCl}$ injection as the UCS to test whether ketamine itself can cause a taste aversion.

Group 9-The rats in this group differed from those in Group 1 in that they received saline instead of an $\mathrm{LiCl}$ injection as the UCS on Day 6. Since the saline injection does not cause malaise, rats store the new CS as "save." Confronted with the saccharin solution a second time (Day 8), they have lost their neophobia and are therefore expected to increase their intake of it.

\section{Statistical Analysis}

For statistical analysis, the absolute amounts of saccharin consumed (in g) on Day 8 (two-bottle choice test) by the ketamineinjected animals (Groups 2-8) were compared with those consumed by the saline-injected animals of Group 1. Furthermore, on Day 8 , the saccharin consumption of Group 8 (ketamine as the UCS) was compared with that of Group 9 (saline as the UCS). Intergroup comparisons were made using the Mann-Whitney $U$ test, except for comparison of amounts of saccharin drunk on Day 6, when the KruskalWallis test was used.

\section{RESULTS}

The results for the first four groups are summarized in Figure 1. The rats in the control group $(0 \mathrm{mg} / \mathrm{kg})$, as well as those in the 6- and $12-\mathrm{mg} / \mathrm{kg}$ ketamine groups, displayed an almost total avoidance of the saccharin solution on the choice test (mean saccharin consumption was, respectively, $1.4 \%, 3.3 \%$, and $4.4 \%$ of total fluid consumption). However, the rats in the $25-\mathrm{mg} / \mathrm{kg}$ ketamine group did not learn to avoid the saccharin solution
( $48 \%$ saccharin, $52 \%$ tap water; $p<.01$, U test). Ketamine $(25 \mathrm{mg} / \mathrm{kg})$ injected $30 \mathrm{~min}$ prior to the first presentation of a new taste cue (saccharin solution) blocked the formation of a conditioned taste aversion.

When the new taste cue was already stored, ketamine given before the $\mathrm{LiCl}$ injection did not block the formation of a conditioned taste aversion (Figure 2; PRE-UCS). During the choice test on Day 8 , the rats in Group 5 drank, on the average, only $0.4 \mathrm{~g}$ of saccharin solution but $11.7 \mathrm{~g}$ of water. Ketamine $(25 \mathrm{mg} / \mathrm{kg})$ thus blocked

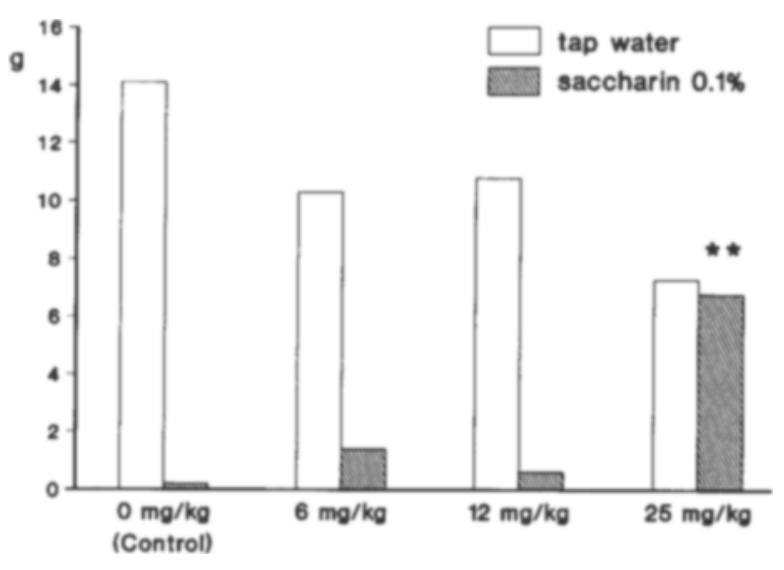

Figure 1. The effects of increasing doses of ketamine injected before the first exposure to a novel taste (0.1\% saccharin solution) on consumption of tap water and saccharin solution (in g) during a twobottle choice test $48 \mathrm{~h}$ after conditioning. The duration of the drinking session was $15 \mathrm{~min}$. Only rats injected with $25 \mathrm{mg} / \mathrm{kg}$ ketamine failed to avoid the saccharin solution. Asterisks indicate significant differences $(p<.01)$ from the saline control group (Mann-Whitney $U$ tests).

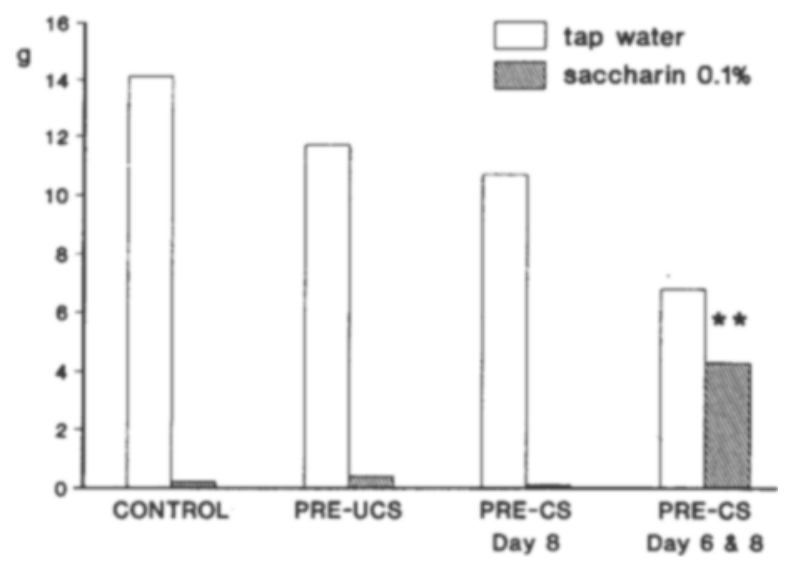

Figure 2. Ketamine (25 mg/kg) injected before the injection of $\mathrm{LiCl}$ (PRE-UCS) or before the two-bottle choice test (PRE-CS/Day 8) did not block the aversion to a saccharin solution $(0.4$ and $0.1 \mathrm{~g}$ consumed, respectively). An injection of ketamine $(25 \mathrm{mg} / \mathrm{kg}$ ) before the first exposure to the new taste as well as before the two-bottle choice test (PRE-CS/Day 6 \& 8) blocked taste-aversion learning $\left({ }^{* *} p<.01, \mathrm{U}\right.$ test $)$. 


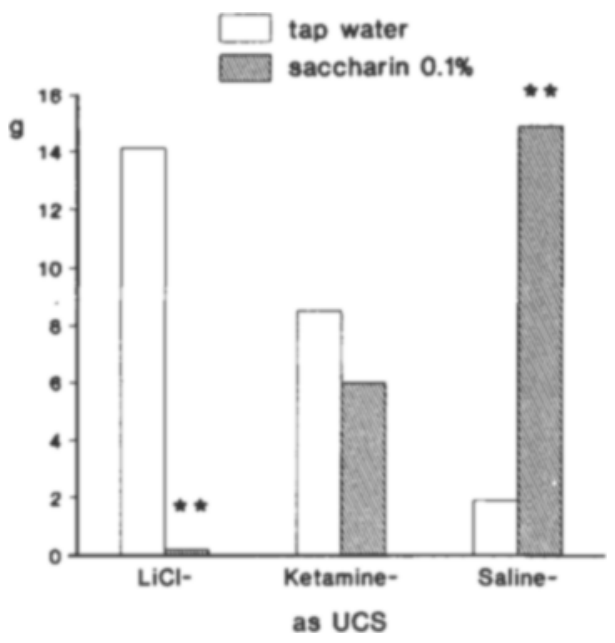

Figure 3. Effect of saline, ketamine ( $25 \mathrm{mg} / \mathrm{kg}$ ), and $\mathrm{LiCl}$ as the UCS on saccharin consumption on Day 8 (two-bottle choice test). Saline-injected animals developed a preference for saccharin, whereas ketamine- or $\mathrm{LiCl}$-injected animals showed a partial or total suppression of saccharin intake. The absolute intake of saccharin (in $\mathrm{g}$ ) for the saline and $\mathrm{LiCl}$ groups was compared with that of the ketamine group $(* * p<.01, \mathrm{U}$ test $)$.

the storage of a new taste cue but did not prevent the association of an already stored taste quality with malaise.

Ketamine $(25 \mathrm{mg} / \mathrm{kg})$ did not block the retrieval of an already established taste-malaise association. The rats in Group 6 avoided the saccharin solution $(0.1 \mathrm{~g})$ and preferred water $(10.7 \mathrm{~g})$ on Day 8 (Figure 2; PRE-CS Day 8). The rats in Group 7, which were injected with ketamine before the first exposure to saccharin (Day 6) and before the choice test (Day 8), did not avoid the saccharin solution ( $4.3 \mathrm{~g}$ saccharin, $6.8 \mathrm{~g}$ water; $p<.01$, $\mathrm{U}$ test) on Day 8 (Figure 2, PRE-CS/Day $6 \& 8$ ).

When ketamine instead of $\mathrm{LiCl}$ was injected as the UCS (Group 8), the rats drank a mean of $6.0 \mathrm{~g}$ of saccharin and $8.5 \mathrm{~g}$ of water (Figure 3 ). This was a significantly higher saccharin intake $(p<.01, \mathrm{U}$ test) than that of the animals of Group 1, which received $\mathrm{LiCl}$ as the UCS. The animals that were injected with saline as the UCS (no malaise; Group 9) developed a preference for the saccharin solution ( $14.9 \mathrm{~g}$ saccharin vs. $1.9 \mathrm{~g}$ water consumed). In contrast to this group, the animals injected with ketamine as the UCS (Group 8) had a significantly lower saccharin consumption $(p<.01, \mathrm{U}$ test).

Although the highest dose of ketamine $(25 \mathrm{mg} / \mathrm{kg})$ induced severe initial motor disturbances, it did not block the animals' motivation to drink. They immediately approached the drinking spout and started licking. In a competition test with 2 thirsty rats and only one water bottle in a cage, drugged as well as undrugged rats fought for access to the drinking spout by pushing the other animal away. The total saccharin consumption of Groups 1-4 on Day 6 was only slightly reduced by ketamine (n.s.,
Kruskal-Wallis). The 0-, 6-, 12-, and $25-\mathrm{mg} / \mathrm{kg}$ groups consumed $13.3,13.8,11.0$, and $10.0 \mathrm{~g}$, respectively.

\section{DISCUSSION}

Our data support a role of the NMDA receptor in the acquisition of a novel gustatory memory trace in tasteaversion learning. Rats injected with ketamine before the first exposure to saccharin, which was followed $1 \mathrm{~h}$ later by malaise, did not learn to avoid the saccharin solution. Rats that had already established an association between saccharin and malaise were able to recognize and avoid saccharin even after an injection of ketamine. Thus, a dose of ketamine interfering with the formation of a gustatory trace did not block the retrieval of an already established taste aversion, nor did it impair the animals' sensory capability to recognize the saccharin solution.

Our findings do not appear to be the result of statedependent learning. When ketamine was administered before both the conditioning session (Day 6) and the choicetest session (Day 8), the results were similar to those found after ketamine injection before the conditioning session alone.

The effect of ketamine on taste-aversion learning resembles the effect of anticholinergic drugs, which also interfere with the formation of the gustatory trace (Deutsch, 1978 ) but not the CS-UCS association (Kral, 1971) or retrieval during a test session (Gadusek \& Kalat, 1975). Furthermore, when the CS was applied under functional decortication, no taste-aversion learning took place (Burěsová \& Burěs, 1973). However, functional decortication did not block the CS-UCS association. In another experiment, Riley and coworkers showed that trimethyltin-treated rats developed a weaker conditioned taste aversion than did untreated control animals (Riley, Dacanay, \& Mastropaolo, 1984). Trimethyltin causes neuronal damage, which is most evident in limbic structures (see, e.g., Whittington, Woodruff, \& Baisden, 1989). These results are especially interesting with respect to our results. NMDA receptors have their highest concentration in cortical structures, including the hippocampus (Monaghan \& Cotman, 1985). Ketamine therefore interferes, at least in part, with cortical functions, and this interference might be responsible for its amnesic effect.

A number of other learning tasks are impaired after central or peripheral applications of NMDA receptor antagonists. Spatial tasks are especially sensitive to such a blockade. Thus, antagonists of the NMDA receptor cause learning impairments in a water maze (Alessandri et al., 1989; Morris et al., 1986; Whishaw \& Auer, 1989), a radial maze (Danysz, Wroblewski, \& Costa, 1988; Kesner, Hardy, \& Novak, 1983), or a T maze (Handelmann, Contreras, \& O'Donohue, 1987). But passive and active avoidance learning and the acquisition of visual discrimination tasks are also impaired by NMDA receptor blockade (Benvenga \& Spaulding, 1988; Danysz et al., 1988; 
Kesner et al., 1983; Tang \& Franklin, 1983; Tang \& Ho, 1988). Deficits in spatial learning after injection of NMDA antagonists could be attributed to motor disturbances induced by these drugs (e.g., see Tang \& Ho, 1988). However, it is not likely that motor disturbances were responsible for the failure to acquire a taste aversion. Olfactory-discrimination learning, another task in which motor performance plays a minor role, is also impaired by the injection of a competitive NMDA antagonist (Staubli, Thibault, DiLorenzo, \& Lynch, 1989).

Ketamine, as well as phencyclidine, have been reported to induce taste aversion in mice and rats (Etscorn \& Parson, 1979; Jackson \& Sanger, 1989) when injected (instead of, e.g., $\mathrm{LiCl}$ ) after the exposure to a novel taste. Phencyclidine as the UCS failed to induce taste aversion to saccharin in other experiments using rhesus monkeys and rats as subjects (Wilcoxon \& Etscorn, 1976, cited in Etscorn \& Parson, 1979; Kesner, Hardy, \& Calder, 1981). Our animals developed a taste aversion with ketamine as the UCS; that is, they reduced their saccharin intake relative to that of animals receiving a saline injection as the UCS. The suppression of saccharin intake, however, was not complete, and therefore saccharin intake was much higher than that observed in animals that received an $\mathrm{LiCl}$ injection as the UCS. Ketamine might have failed to suppress the CS-UCS association in Group 5 due to its own aversive properties, or because the effect of $\mathrm{LiCl}$ outlasts that of ketamine. On the other hand, a lack of effect of ketamine on the CS-UCS association would fit well with other data demonstrating the robustness of the CS-UCS association taking place even during functional decortication (Burěsová \& Burěs, 1973). Neither of these possibilities can be excluded on the basis of our data.

Ketamine blocks NMDA receptors (Anis, Berry, Burton, \& Lodge, 1983) but also influences a number of other neurotransmitter systems or ion channels. Among its other effects, ketamine interacts with the ion channel of the acetylcholine receptor at the neuromuscular junction (Maleque, Warnick, \& Albuquerque, 1981) and inhibits serotonin uptake (Martin, Bouchal, \& Smith, 1982). Although non-NMDA effects are usually obtained only after dosages of ketamine that are higher than those used in our experiments, the contribution of non-NMDA effects to conditioned taste aversion cannot be excluded.

In conclusion, the noncompetitive NMDA antagonist ketamine blocked the formation of a new gustatory trace for saccharin in a taste-aversion paradigm. The association of the new taste with malaise and the retrieval of the learned association were not impaired by ketamine.

\section{REFERENCES}

Alessandri, B., Bättig, K., \& Welzl, H. (1989). Effects of ketamine on tunnel maze and water maze performance in the rat. $B e$ havioral \& Neural Biology, 52, 194-212.

Anis, N. A., Berry, S. C., Burton, N. R., \& Lodge, D. (1983). The dissociative anaesthetics, ketamine and phencyclidine, selectively reduce excitation of central mammalian neurones by $\mathrm{N}$-methylaspartate. British Journal of Pharmacology, 79, 565-575.

Benvenga, M. J., \& Spaulding, T. C. (1988). Amnesic effect of the novel anticonvulsant MK-801. Pharmacology, Biochemistry \& Behavior, 30, 205-207.

BuRĚSová, O., \& BuRĚs, J. (1973). Cortical and subcortical components of the conditioned saccharin aversion. Physiology \& Behavior, $11,435-439$.

BurĚSOVÁ, O., \& BURĚs, J. (1977). The effect of anesthesia on the acquisition and extinction of conditioned taste aversion. Behavioral Biology, 20, 41-50.

Collingridge, G. L., Kehl, S. J., \& McLennan, H. (1983). Excitatory amino acids in synaptic transmission in the Schaffer collateralcommissural pathway of the rat hippocampus. Journal of Physiology (London), 334, 33-46.

Danysz, W., Wroblewski, J. T., \& Costa, E. (1988). Learning impairment in rats by $\mathrm{N}$-methyl-D-aspartate receptor antagonists. Neuropharmacology, 27, 653-656.

DEUTSCH, R. (1978). Effects of atropine on conditioned taste aversion. Pharmacology, Biochemistry \& Behavior, 8, 685-694.

Dragoin, W., McCleary, G. E., \& McCleary, P. (1971). A comparison of two methods of measuring conditioned taste aversions. Behavior Research Methods \& Instrumentation, 3, 309-310.

Etscorn, F., \& PARSON, P. (1979). Taste aversion in mice using phencyclidine and ketamine as the aversive agents. Bulletin of the Psychonomic Society, 14, 19-21.

GaduSEK, F. J., \& Kalat, J. W. (1975). Effects of scopolamine on retention of taste-aversion learning in rats. Physiological Psychology, 3, 130-132.

Grote, F. W., JR., \& Brown, R. T. (1971). Conditioned taste aversions: Two-stimulus tests are more sensitive than one-stimulus tests. Behavior Research Methods \& Instrumentation, 3, 311-312.

Handelmann, G. E., Contreras, P. C., O'Donohue, T. L. (1987). Selective memory impairment by phencyclidine in rats. European Journal of Pharmacology, 140, 69-73.

JACKSON, A., \& SANGER, D. J. (1989). Conditioned taste aversions induced by phencyclidine and other antagonists of N-methyl-D-aspartate. Neuropharmacology, 28, 459-464.

Kesner R. P., Hardy, J. D., \& Calder, L. D. (1981). Phencyclidine and behavior: I. Sensory-motor function, activity level, taste aversion and water intake. Pharmacology, Biochemistry \& Behavior, 15, 7-13.

Kesner R. P., Hardy, J. D., \& Novak, J. M. (1983). Phencyclidine and behavior: II. Active avoidance learning and radial arm maze performance. Pharmacology, Biochemistry \& Behavior, 18, 351-356.

KRAL, P. A. (1971). Effects of scopolamine injection during CS-US interval on conditioning. Psychological Reports, 28, 690.

Maleque, M. A., Warnick, J. E., \& Albuquerque, E. X. (1981). The mechanism and site of action of ketamine on skeletal muscle. Journal of Pharmacology \& Experimental Therapeutics, 219, 638-645.

Martin, L. L., Bouchal, R. L., \& Smith, D. J. (1982). Ketamine inhibits serotonin uptake in vivo. Neuropharmacology, 21, 113-118.

Monaghan, D. T., \& Cotman, C. W. (1985). Distribution of N-methylD-aspartate-sensitive L- $\left[{ }^{3} \mathrm{H}\right]$ glutamate-binding sites in rat brain. Journal of Neuroscience, 5, 2909-2919.

Morris, R. G. M., Anderson, E., Lynch, G. S., \& Baudry, M. (1986). Selective impairment of learning and blockade of long-term potentiation by an N-methyl-D-aspartate receptor agonist, AP5. $\mathrm{Na}$ ture, 319, 774-776.

Riley, A. L., Dacanay, R. J., \& Mastropaolo, J. P. (1984). The effects of trimethyltin chloride on long-delay taste aversion learning in the rat. Neurotoxicology, 5, 291-296.

Rondeau, D. B., Jolicoeur, F. B., Merkel, A. D., \& Wayner, M. J. (1981). Drugs and taste aversion. Neuroscience \& Biobehavioral Reviews, 5, 279-294.

SMrth, S. J. (1987). Progress on LTP at hippocampal synapses: A postsynaptic $\mathrm{Ca}^{2+}$ trigger for memory storage? Trends in Neuroscience, 10, 142-144.

Staubli, U., Thibault, O., Dilorenzo, M., \& Lynch, G. (1989). Antagonism of NMDA receptors impairs acquisition but not retention of olfactory memory. Behavioral Neuroscience, 103, 54-60. 
Stringer, J. L., \& Guyenet, P. G. (1983). Elimination of long-term potentiation in the hippocampus by phencyclidine and ketamine. Brain Research, 258, 159-164.

TANG, A. H., \& Franklin, S. R. (1983). Acquisition of brightness discrimination in the rat is impaired by opiates with psychotomimetic properties. Pharmacology, Biochemistry \& Behavior, 18, 873-877.

TANG, A. H., \& Ho, P. M. (1988). Both competitive and non-competitive antagonists of $\mathrm{N}$-methyl-D-aspartic acid disrupt brightness discrimination in rats. European Journal of Pharmacology, 151, 143-146.
Whishaw, I. Q., \& Auer, R. N. (1989). Immediate and long-lasting effects of MK-801 on motor activity, spatial navigation in a swimming pool and EEG in the rat. Psychopharmacology, 98, 500-507. Whittington, D. L., WoodrufF, M. L., \& Baisden, R. H. (1989). The time-course of trimethyltin-induced fiber and terminal degeneration in hippocampus. Neurotoxicology \& Teratology, 11, 21-33.

(Manuscript received September 8, 1989; revision accepted for publication December 20, 1989.) 